\title{
NICOTINIC ACID IN THE TREATMENT OF ANGINA PECTORIS
}

\author{
BY \\ WILFRED STOKES \\ From Oldchurch Hospital, Romford, Essex
}

Received June 29, 1944

Glyceryl trinitrate has had no equal in the relief and prevention of the anginal attack. The claims of new drugs must, however, be tested if their pharmacological action includes dilatation of the coronary artery and if clinical benefit has been observed.

Since improvement in patients with angina pectoris has been reported recently by Moncrieff (1942) and Neuwahl (1942) from treatment with nicotinic acid, it became necessary to test the drug in a series of cases under controlled conditions. Moncrieff recorded benefit in three patients with doses varying from 10 to $50 \mathrm{mg}$. by mouth. Neuwahl claimed prolonged improvement in six patients after intravenous administration : one of these had received antisyphilitic treatment for aortitis, another showed aortic incompetence and great dilatation of the aorta, and a third with mitral stenosis was subject to paroxysmal auricular fibrillation ; electrocardiography was not a part of the examination, and no mention was made of the period of rest associated with the nicotinic acid infusions of which six were given within three weeks. Transient benefit was also claimed from oral administration of the drug, but no dosage was mentioned. Masek (1940) watched temporary improvement in four cases of old cardiac infarction, and in three with coronary sclerosis and angina pectoris, after the intravenous injection of the chloride of nicotinic acid in doses up to $0.16 \mathrm{~g}$. He suggested that this effect might not only be due to coronary dilatation but also to an improvement in the metabolism of the myocardium by saturation with coenzymes.

The conversion of sugar to pyruvic acid and lactic acid occurs in a series of steps through intermediary substances so that a gradual supply of energy is liberated in the tissues (Eddy and Dalldorf, 1941). Involved in the type of oxidation which is based on hydrogen transfer, are many factors including " hydrogen acceptors," such as nicotinic acid amide. This is combined in the molecules of coenzyme I (diphospho-pyridine-nucleotide) and of coenzyme II (triphospho-pyridine-nucleotide) which are sometimes collectively termed the $\mathrm{V}$ factor. In man the administration of nicotinic acid causes a considerable rise in the level of the V factor in the blood (Kohn, Klein, and Dann, 1939) which should in theory assist the removal of lactic acid and other products of metabolism from the myocardium. If the accumulation of such substances plays some part in the causation of anginal pain, a rise in the coenzyme level of the blood and tissues should be beneficial in myocardial ischæmia. For this purpose the amide of nicotinic acid would be as efficacious as nicotinic acid itself, but would cause no vasodilatation (Field and Robinson, 1940).

Rachmilewitz and Braun (1944) discussing the cardiographic changes in nicotinic acid deficiency have assumed that an altered metabolic state of the heart is due to lack of coenzyme. In spite of the fact that the nicotinic acid intake on an average middle-class diet is perilously low (Kodicek, 1942), even minor degrees of deficiency must be very uncommon in this country. It is significant too, that $I$ have found no reference to the common association of angina pectoris with pellagra, even in the elderly. In view of the possibility that an increment in coenzymes might mitigate the anginal pain, the amide of nicotinic acid has been employed as well as nicotinic acid in the present clinical trial.

The cutaneous response to nicotinic acid in the form of flushing has shown great variation not only in different subjects, but in the same subject at different times (Spies, Bean, and Stone, 1938 ; Sebrell and Butler, 1938). Although occasional flushing may result from doses as low as $25 \mathrm{mg}$., doses upward of $500 \mathrm{mg}$. are required to produce for certain a degree of peripheral effect. Experimental proof of general systemic vasodilatation and clinical observation in the 
treatment of peripheral vascular disease have been disappointing. Popkin (1939) found that variations in surface temperatures were inconstant and that the amplitude of oscillometric readings actually diminished in most cases. Other investigators (Abramson, Katzenstein, and Senior, 1940) showed that a significant increase of blood flow was generally elicited in the hand and forearm with only a slight increase in the leg. As regards coronary dilatation there is as yet no definite evidence that this is produced by nicotinic acid. Quite apart from the inconstancy of vasodilatation as measured by peripheral flushing, the reaction does not take place for 10 to 20 minutes after the drug is taken by mouth and lasts a similar time. The peripheral effects, to say the least, are unpleasant ; and nicotinic acid on this account would be unpopular for routine use if flushing were an essential aim.

\section{Description of Clinical Trial}

In this investigation cases of angina pectoris were selected according to the criteria adopted by Evans and Hoyle (1933). Thus each patient had angina pectoris of effort, characterized by sub-sternal pain that spread across the chest, often through to the back, or to the shoulders, down one or both arms, or occasionally to the jaw and neck. The attack was always determined by physical exertion. Emotion sometimes induced an attack in some of the cases, but only where physical movement would bring on the pain as readily. Eight of the ten patients had had cardiac infarction at some previous date, but sufficient time had elapsed for maximum myocardial recovery to occur ; one of the remaining two had hypertension, and the other with classical anginal attacks had a normal cardiogram. All cases were studied as ambulant out-patients. Clinical examination included cardioscopy and cardiography and a Wassermann reaction was sometimes taken. The drugs given and doses employed are indicated in Table I. Each test period lasted at least one week, and this was often repeated. There was no particular sequence, and a placebo in the form of ascorbic acid or a gentian mixture was interspersed at intervals. All drugs were taken orally and swallowed, except for glyceryl trinitrate which was chewed. Nicotinic acid was employed in doses of 50 to $100 \mathrm{mg}$. prophylactically, and for the direct relief of the painful attack in some of the cases. In all cases during further trial periods it was given in regular doses of 25 or $50 \mathrm{mg}$., up to $200 \mathrm{mg}$. daily. Similarly nicotinamide was given in amounts up to $400 \mathrm{mg}$. in a day. It will be observed from the tabulated results that no greater benefit resulted from nicotinic acid or from nicotinamide than from a placebo. Improvement or deterioration that occurred during

TABLE I

EFFECT ON PAIN IN 10 PATIENTS WITH ANGINA OF NICOTINIC ACID AND NICOTINAMIDE COMPARED WITH THAT OBTAINED FROM PLACEBO AND GLYCERYL TRINITRATE

\begin{tabular}{c|c|c|c|c|c|c|c|c|c|c|c}
\hline Drug & Dose and Method & 1 & 2 & 3 & 4 & 5 & 6 & 7 & 8 & 9 & 10 \\
\hline $\begin{array}{c}\text { Nicotinic } \\
\text { Acid }\end{array}$ & $\begin{array}{c}50-100 \text { mg. for relief } \\
\text { and prevention. }\end{array}$ & & & & - & & - & & + & & \\
\cline { 2 - 7 } & $\begin{array}{c}\text { Up to 200 mg. daily in } \\
3 \text { or 4 doses. }\end{array}$ & + & - & - & - & + & - & - & + & - & - \\
\hline $\begin{array}{c}\text { Nicotin- } \\
\text { amide }\end{array}$ & $\begin{array}{c}\text { 200-400 mg. daily in } \\
4 \text { doses. }\end{array}$ & - & + & + & - & - & + & + & - & - & - \\
\hline $\begin{array}{c}\text { Ascorbic } \\
\text { Acid }\end{array}$ & $\begin{array}{c}\text { For relief and preven- } \\
\text { tion, 3-4 doses daily. }\end{array}$ & + & - & + & - & + & - & + & - & - & + \\
\hline $\begin{array}{c}\text { Gentian } \\
\text { Mixture }\end{array}$ & $\begin{array}{c}\text { Three doses daily. } \\
\text { Glyceryl }\end{array}$ & + & + & - & - & & - & - & & - & \\
\hline Trinitrate & $\begin{array}{c}\text { For relief and preven- } \\
\text { tion. }\end{array}$ & ++ & ++ & ++ & ++ & ++ & ++ & ++ & ++ & ++ & ++ \\
\hline
\end{tabular}

++ indicates great benefit ; + , slight benefit ; - , no benefit. 
the trial periods could be explained by the natural variation in the severity and frequency of anginal attacks associated with or apart from changes in external influences. Thus, nicotinic acid failed to fulfil the postulates suggested by Evans (1944) as forming a statutory standard of efficiency for drugs. On the other hand great benefit was obtained in each patient from the use of glyceryl trinitrate ; it quickly relieved the attack when it had developed, and greatly reduced the number of attacks when a tablet was chewed before any exercise that customarily induced pain.

Toxic effects. Bean and Spies gave nicotinic acid to over a thousand subjects without toxic effects (Bicknell and Prescott, 1942). A fall in blood pressure from 190/100 to 110/80 was reported by Popkin (1939) after the administration of $100 \mathrm{mg}$. of nicotinic acid to a woman of 50 with essential hypertension. Other unpleasant effects after the oral administration of large doses have been reported, including true angor animi in one subject (Spies, Bean, and Stone 1938), dizziness, nausea, cramp in the epigastrium, vomiting, mental depression, palpitation, and urticaria. In the present trial severe flushing effects were reported by four patients. One felt tightness in the chest after a dose of $50 \mathrm{mg}$. and had to discontinue the drug because of faintness after taking eleven such doses within three days. His pain became worse. Another patient felt giddy after $50 \mathrm{mg}$., but later did not particularly mind a severe flushing reaction after $100 \mathrm{mg}$. The other two tolerated flushing well, but had no relief from pain. As expected, no such peripheral reactions occurred after nicotinamide.

\section{Electrocardiographic Changes}

Irregularities in the $\mathrm{R}-\mathrm{T}$ segment and the $\mathrm{T}$ wave associated with anginal pain have been described by Parkinson and Bedford (1931) and by Goldhammer and Scherf (1932), but there
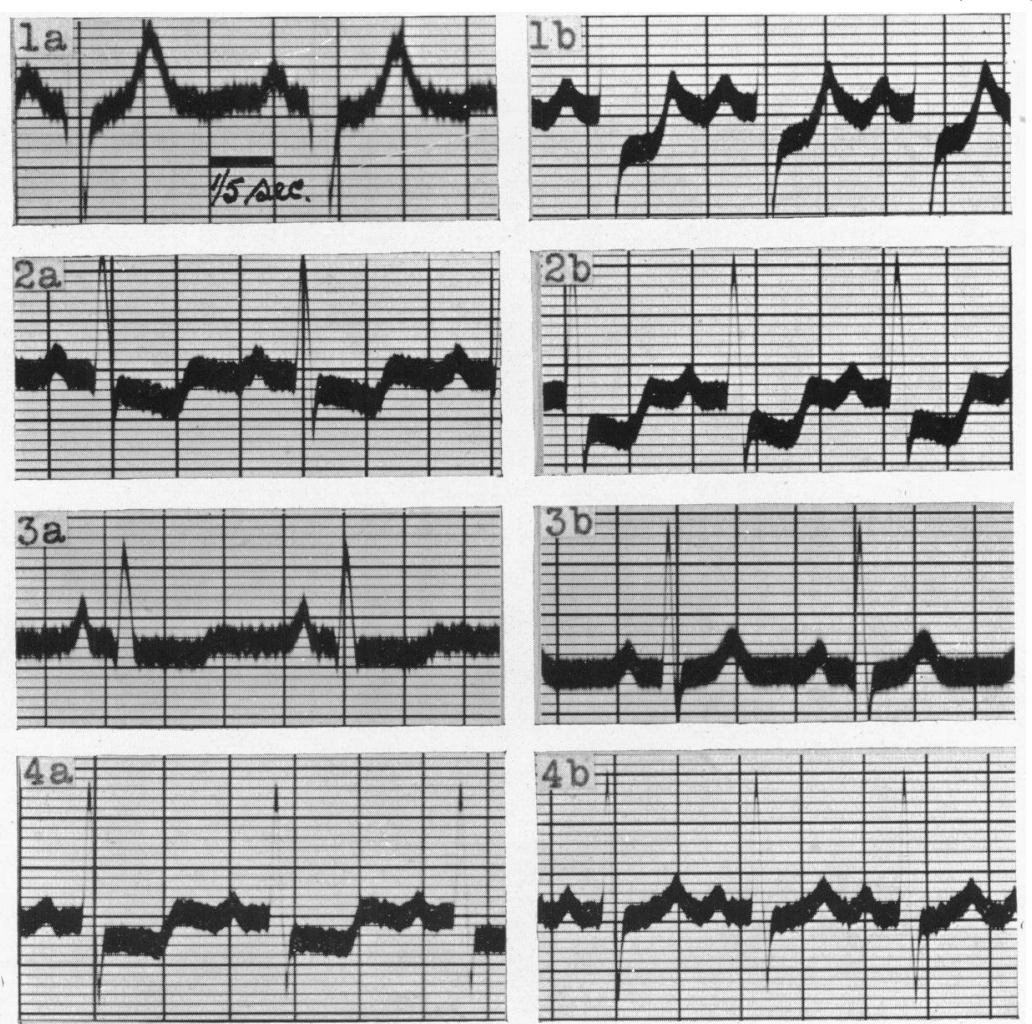

FIG. 1.-Changes in the electrocardiogram (lead IVR) of a patient with cardiac ischæmia, following the administration of nicotinic acid and glyceryl trinitate (see next page).

(1a) at rest. (1b) after exercise inducing pain.

(2a) at rest. (2b) 25 minutes after $200 \mathrm{mg}$. nicotinic acid which failed to cause flushing.

(3a) at rest. (3b) 24 minutes after $300 \mathrm{mg}$. nicotinic acid which caused generalized flushing.

(4a) at rest. (4b) 4 minutes after chewing glyceryl trinitrate gr. 1/100. 
is a difference of opinion as to the frequency and character of such cardiographic variations (Freedberg et al., 1941). These changes induced by anoxæmia have been employed by Levy and others (1939) as a test for coronary efficiency. Glyceryl trinitrate may correct such cardiographic variations (Evans and Hoyle 1933), so that the effect of nicotinic acid upon the abnormal electrocardiogram was tested in one case. In this patient exercise in the form of raising and lowering the legs to a standard height from the couch caused depression of the $\mathrm{R}-\mathrm{T}$ segment.

The effect of nicotinic acid in preventing and correcting this deformity was observed and compared with that produced by glyceryl trinitrate (Fig. 1). When $200 \mathrm{mg}$. of nicotinic acid was given by mouth it did not cause flushing, neither did it prevent pain induced by exercise, nor R-T depression in the cardiogram. After $300 \mathrm{mg}$., which produced a severe flush, pain and $\mathrm{R}-\mathrm{T}$ depression were prevented until the flush was passing. Absence of pain and cardiographic changes were noted on one occasion when flushing was induced by $150 \mathrm{mg}$. It has been widely assumed that depression of the $\mathrm{R}-\mathrm{T}$ segment and inversion of the $\mathrm{T}$ wave associated with exercise are indications of coronary insufficiency. If these cardiographic changes are prevented by a drug administered before exercise, or corrected should they have already taken place, it might be reasonable to deduce that coronary blood flow has been improved thereby. Further observations on the effects of known coronary dilators on such cardiographic changes need to be carried out. Meanwhile these results appear to indicate that coronary dilatation does accompany the peripheral vascular effects of nicotinic acid, but that flushing is necessary and is variable in development even with large doses. After glyceryl trinitrate with the exception of periods when records were made at 4,6 , and 8 minutes after the tablet was chewed, exercise was continued until the patient was tired and breathless. No pain nor R-T depression resulted.

\section{CONCLUSIONS}

Changes in the electrocardiogram of cardiac ischæmia in man, following the administration of nicotinic acid, suggest that the drug can improve coronary blood flow; but this only results from a dosage large enough to produce peripheral flushing, which in itself is an uncertain and unpleasant effect.

In a controlled clinical trial no improvement resulted from the oral administration of nicotinic acid in moderate dosage, either in the prevention or relief of angina, and nicotinamide in larger doses failed to give better results.

Once again glyceryl trinitrate has shown that it has no equal in the treatment of angina pectoris, and nicotinic acid has no claim to routine use in this complaint.

I am indebted to Dr. William Evans for his advice in the preparation of this paper, and to Dr. E. Miles for facilities for the investigation.

\section{REFERENCES}

Abramson, D. I., Katzenstein, K. H., and Senior, F. A. (1940). Amer. J. med. Sci., 200, 96.

Bicknell, F., and Prescott, F. (1942). The Vitamins in Medicine. London.

Eddy, W. H., and Dalldorf, G. (1941). The Avitaminoses. Baltimore.

Evans, W. (1944). Brit. med. J., 1, 371.

Evans, W., and Hoyle, C. (1933). Quart. J. Med., 2, 311.

- (1933). Lancet, 1, 1109.

Field, H., and Robinson, W. D. (1940). Amer. J. med. Sci., 199, 255.

Freedberg, A. S., Riseman, J., and Spiegel, E. D. (1941). Amer. Heart J., 22, 494.

Goldhammer, St., and Scherf, D. (1932). Z. Klin. Med., 122, 134.

Kodicek, E. (1942). Lancet, 1, 380.

Kohn, H. I., Klein, J. R., and Dann, W. J. (1939). Biochem. J., 33, 1432.

Levy, R. L., Bruenn, H. G., and Russell, N. G. (1939). Amer. J. med., Sci., 197, 241.

Masek, J., and Svatos, F. (1940). Casop. lek. Cesk., 79, 793.

Moncrieff, A. (1942). Lancet 1, 633.

Neuwahl, F. G. (1942). Ibid., 2, 419.

Parkinson, J., and Bedford, D. E. (1931). Ibid., 1, 15.

Popkin, R. J. (1939). Amer. Heart J., 18, 697.

Rachmilewitz, M., and Braun, K. (1944). Ibid., 27, 203.

Sebrell, W. H., and Butler, R. E. (1938). J. Amer. med. Ass., 111, 2286.

Spies, T. D., Bean, W. B., and Stone, R. E. (1938). Ibid., 111, 584. 